International Journal of Bioscience and Medicine
(ISSN:2575-7814)

\title{
Antioxidant Activity and Hemotoxicity of Medicinal Plant of the Caatinga Domain: Amburana Cearensis (Fabaceae)
}

João Victor de Oliveira Alves ${ }^{1 *}$, Francisco Henrique da Silva ${ }^{1}$, Maria Victoria dos Santos Alves Evaristo², Janderson Weydson Lopes Menezes da Silva ${ }^{3}$, Paloma Maria da Silva', Larissa Gomes de Arruda ${ }^{1}$, Irivânia Fidelis da Silva Aguiar ${ }^{1}$, Saulo Almeida de Menezes ${ }^{1}$, Fálba Bernadete Ramos dos Anjos ${ }^{4}$, Márcia Vanusa da Silva ${ }^{1}$

${ }^{1}$ Biochemistry Department, Universidade Federal de Pernambuco, Recife, Pernambuco, Brazil;

${ }^{2}$ Graduated in Biological Sciences, Institute of Biological Cienicas, Campus Santo Amaro, Universidade de Pernambuco; ${ }^{3}$ Aggeu Magalhães Institute (IAM) - FIOCRUZ/PE, Brazil. ${ }^{4}$ Department of Histology and Embryology, Universidade Federal de Pernambuco, Recife, Pernambuco, Brazil

\section{ABSTRACT}

Amburana cearensis is a medicinal species popularly known as "cherry" or "aroma amburana" that has wide distribution in South America, being characteristic of Seasonal Forests. It also occurs in Semideciduous Seasonal Forest, restricted to rocky or limestone outcrops; in Submontane Deciduous SubmontanaSeasonalForest; in Dense Ombrophilous Forest (Atlantic Forest) and even in caatinga/dry forest. Taking into account the growing interest in the search for agents that act in the face of oxidative stress, without causing toxic effects to biological systems, the present study aimed to investigate the phytochemical composition and evaluate the antioxidant and hemotoxic activities in vitro of the aqueous extract obtained from the shells of Amburana cearensis (EAAc). Hemaglutination wasevaluated for human erythrocytes collected from people with the presence of $\mathrm{O}+$ blood. In the face of the tests, Amburana cearensis presented significant results for antioxidant activity without causing erythrocyte hemolysis, highlighting the importance of the species as a source of antioxidant agents, which are recognized for blocking the evolution and acting to combat symptoms triggered by diseases associated with oxidative stress.

Keywords: Caatinga. Aqueousextract. Erythrocytes. Free radicals.

*Correspondence to Author: João Victor de Oliveira Alves Biochemistry Department, Universidade Federal de Pernambuco, Recife, Pernambuco, Brazil;

How to cite this article:

João Victor de Oliveira Alves, Francisco Henrique da Silva, Maria Victoria dos Santos Alves Evaristo, Janderson Weydson Lopes Menezes da Silva, Paloma Maria da Silva, Larissa Gomes de Arruda, Irivânia Fidelis da Silva Aguiar, Saulo Almeida de Menezes, Fálba Bernadete Ramos dos Anjos, Márcia Vanusa da Silva1.Antioxidant Activity and Hemotoxicity of Medicinal Plant of the Caatinga Domain: Amburana Cearensis (Fabaceae) International Journal of Bioscience and Medicine, 2020; 4:13.

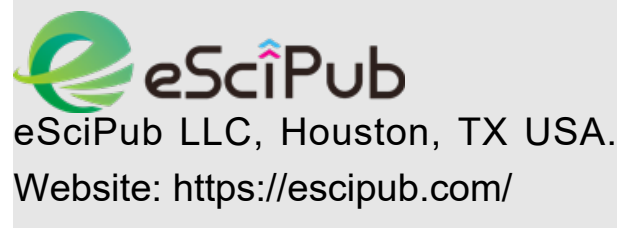




\section{INTRODUCTION}

The knowledge left through indigenous traditions, quilombolas and other ethnicgroups were of great importance to disseminate empirical knowledge of medicinal plants, being fundamental for the discovery of new therapeutic substances that may or may not produce toxic effects $^{1}$. Due to their chemical diversity and the actions of evolutionary and adaptive effects on plants, these events end up contributing to the creation of new biologically active molecules that are part of the phytopharmaceuticals used in the clinic $^{2}$.

Amburana cearensis (Allemão) A.C. Smith, Fabaceae, is an erect stem tree, which reaches 10 to $12 \mathrm{~m}$ in height ${ }^{3}$. The species is also known as cumaru, cumaru-de-cheiro, cherry and, due to its timber qualities, has been exploited in the places of occurrence until exhaustion, for use in fine furniture, sculptures and joinery in general, being listed as an endangered species ${ }^{4}$. The species has a wide distribution in South America, being characteristic of Seasonal Forests. It also occurs in the Caatinga/Dry forest domain 5 .

In addition, due to their medicinal properties, tree bark and seeds are used in the production of popular medicines intended for the treatment of lung diseases, coughs, asthma, bronchitis and pertussis. The perfumery industry also makes use of this species ${ }^{6}$. Currently, antioxidant agents are recognized for blocking evolution and acting to combat symptoms triggered by diseases associated with oxidative stress ${ }^{7,8}$. Therefore, the objective of this work was to investigate the phytochemical composition, to evaluate the antioxidant and hemotoxic capacity of the aqueous extract of the barks of Amburana cearensis..

\section{MATERIAL AND METHODS}

\subsection{Extract Collection and Production}

The shells of Amburana cearensis were collected at the Armadillo Bola Wildlife Refuge located in the Pernambucano hinterland. The floral parts were deposited to the Agronomic
Institute of Pernambuco (IPA) with identification 95186. The shells were brought to the Biochemistry department - Campus Recife UFPE, where they were dried for $48 \mathrm{~h}$ in a greenhouse at $40{ }^{\circ} \mathrm{C}$ and crushed after drying. The powder obtained was used for the production of aqueous extract. The extracts were prepared under reflux, in a water bath at $100{ }^{\circ} \mathrm{C}$ for 30 minutes, in the proportion $10 \%$ $(w / v)$. At the end, they were cooled and filtered under vacuum with cotton. They were then kept under refrigeration for 3 days. Finally, they were submitted to the lyophilization process for $48 \mathrm{~h}$ to obtain the aqueous crude extracts.

\subsection{Phytochemical Analysis}

The extracts and patterns were applied manually in chromatographic plates of silica gel $60-\mathrm{F}_{254}$. The plates were developed in vats after saturation with the mobile phase (Chart 1). The tank was saturated for approximately 30 minutes at room temperature. The bands were applied with a width of $5 \mathrm{~mm}$ and with a distance between them and the edges of the plates of 5 $\mathrm{mm}$. The length and width size of the chromatographic plates was $10 \times 20 \mathrm{~cm}$. The samples were applied to $5 \mathrm{~mm}$ of the origin and with $5 \mathrm{~mm}$ end of the end of the plate. After elution of the plates they were dried at room temperature and observed under ultraviolet light of 254 and $365 \mathrm{~nm}$ and visible light, then were scanned. Subsequently, they were revealed with specific reagents for each metabolite (Chart 1). The bands obtained were compared to the bands of the corresponding patterns.

\subsection{Antioxidant Activity by the DPPH Method}

The activity of dpph-free radical of the EAAc was performed according to BrandWilliams et al. $(1995)^{9}$ with some modifications. To perform antioxidant activity, $0.008 \mathrm{~g}$ of DPPH was diluted in $100 \mathrm{~mL}$ of methanol, which was later read in ELISA $\AA$ in the length of $517 \mathrm{~nm}$ to obtain UVVIS absorbance between 0.6-0.7. $1 \mathrm{mg}$ of the extract was diluted in $1 \mathrm{~mL}$ of water obtaining a solution at the concentration of $1000 \mu \mathrm{g} / \mathrm{mL}$ where serial dilutions up to $16 \mu \mathrm{g} / \mathrm{mL}$ were performed. In plates of 96 wells, $40 \mu \mathrm{L}$ of each 
concentration were added in $250 \mu \mathrm{L}$ of dpph solution and after 30 minutes of incubation in the dark, absorbances were read at the same wavelength mentioned above. The assays were performed in triplicate and the squeaster capacity of $\mathrm{H}+$ was obtained based on the percentage of reduction of the DPPH, calculated by the following formula:

$\mathrm{SRL}(\%)=\frac{A B S \text { CONTROLE }-A B S \text { AMOSTRAS }}{A B S \text { CONTROLE }} X 100$

Where: ABS control is the radical with methanol and ABS samples is the Radical with the extract.

Table 1 - Systems, developers and patterns used.

\begin{tabular}{|l|l|l|l|}
\hline Metabolite Class & System & Developer & Default \\
\hline Hidrolisables tannins & $90: 5: 5$ & NEU + PEG & Galic acid and Elargic acid. \\
\hline Condensed tannins & $90: 5: 5$ & Hydrochloric vanillin & Catechin \\
\hline Flavonoids & $90: 5: 5$ & NEU + PEG & Quercetin and Rutin \\
\hline Cinamic derivatives & $90: 5: 5$ & NEU + PEG & $\begin{array}{l}\text { Cafeic acid and. Chlorogenic } \\
\text { acid }\end{array}$ \\
\hline Cumarins & $50: 50: 50$ & $\mathrm{KOH}+\Delta$ & Coumarin \\
\hline
\end{tabular}

Legend: $\mathrm{NEU}=$ =thyl borilaminosester acid; $\mathrm{PEG}=$ Polyethylene glycol

\subsection{Total Antioxidant Capacity}

The total antioxidant capacity (\% TAC) was evaluated by the phosphomolybdenum reduction assay according to Prieto et al $(1999)^{10} .1 \mathrm{mg}$ of the extract was diluted in $1 \mathrm{~mL}$ of water, of which an aliquot of $100 \mu \mathrm{L}$ was combined with $1 \mathrm{~mL}$ of reagent solution $(600 \mathrm{mM}$ sulphuric acid, $28 \mathrm{mM}$ of sodium phosphate and ammonium molybdate $4 \mathrm{~mm}$ ). The $1.5 \mathrm{~mL}$ microtubes were covered and incubated in a dry water bath for $90^{\circ} \mathrm{C}$ for $90 \mathrm{~min}$. Subsequently, absorbance was measured at $695 \mathrm{~nm}$ against a blank ( $1 \mathrm{~mL}$ of reagent and $100 \mu \mathrm{L}$ of solvent). Total antioxidant activity was expressed in relation to ascorbic acid.

\subsection{Hemotoxic Activity}

The samples of $5 \mathrm{~mL}$ blood were obtained from healthy volunteers of type $\mathrm{O}+$ by venous puncture and placed in heparinized tubes. To obtain the erythrocytes, the blood was centrifuged (1500 rpm for $10 \mathrm{~min}$ ) and washed three times with phosphate-buffered saline solution (PBS, pH 7.4). A phosphate buffered saline solution (PBS, pH 7.4 to $1 \%$ of erythrocytes) was prepared. To perform the activity, each test tube received $1.1 \mathrm{~mL}$ of erythrocyte suspension $(1 \%)$ and $0.4 \mathrm{~mL}$ of the various concentrations of the extract (16-1000 $\mu \mathrm{g} / \mathrm{mL}$ ). Negative control and positive control received $0.4 \mathrm{~mL}$ of phosphate-saline buffer and Triton X-100, respectively. After 60 minutes of incubation at room temperature, the cells were centrifuged (1500 rpm for $5 \mathrm{~min}$ ) and the supernatant was used to measure the absorbance of the released hemoglobin at 540 $\mathrm{nm}$. The mean value was calculated from the quadruplicate tests. Hemotoxic activity was expressed in relation to the action of Triton X100 and calculated by the following formula:

Hemotoxic activity $(\%)=[($ Aa- Ab).100]/(Ac-Ab) . Being, Aa - absorbance of the sample, Ab absorbance of negative control (phosphatesaline) and Ac - absorbance of positive control (Triton X-100).

\section{RESULTS AND DISCUSSION}

\subsection{Phytochemical Analysis}

The qualitative analysis of the phytochemical content of the EAAc was summarized in Chart 2. The results of this study indicate the presence of 
hydrolysable tannins, flavonoids and coumarins; as well as absence of condensed tannins and cinnamic derivatives.

Several species of medicinal plants contain antioxidant compounds that help in the maintenance of physiological functions in the midst of pathological processes, reducing the harmful effects of toxic agents ${ }^{11}$. Among the bioactive molecules that stand out for their antioxidant capabilities are phenolic compounds, which aid in the sequestration of reactive oxygen species (OEs), reducing their oxidative effects on cellular organic constituents $^{12,13}$.

Table 2 - Phytochemical content of the aqueous extract of amburana cearensis bark (EAAc).

\begin{tabular}{|l|l|l|}
\hline Classe de Metabólito & Extrato & Padrão \\
\hline Taninos Hidrolisáveis & + & Ác. Gálico e Ác elágico \\
\hline Taninos condensados & - & Catequina \\
\hline Flavonoides & + & Quercetina e Rutina \\
\hline Derivados Cinâmicos & - & Ác. Cafeico e Ác. Clorogênico \\
\hline Cumarinas & + & Cumarina \\
\hline
\end{tabular}

The phytochemicals found in this study flavonoids, tannins and coumarins - are part of this group of phenolic substances ${ }^{14}$. Investigations present in the scientific literature report the presence of some flavonoids and coumarins in the ethanolextract of the barks, in the aerial parts and in the xylopodium of $A$. cearensis analyzed by spectroscopic techniques such as NMR, MS and RI ${ }^{15,16}$.

Among the various therapeutic properties attributed to flavonoids, antioxidant and antiinflammatory activities stand out ${ }^{17,18}$, recent literature also points to evidence that indicates a promising role of these compounds in reducing insulin resistance and combating the carcinogenic process of the breasts ${ }^{19,20}$.

Coumarins also have several documented biological activities, such as antioxidant, antiinflammatory, antifungal, antihyperglycemic, among others ${ }^{21}$. As for tannins, their astringent properties that confer antimicrobial, antifungal, healing and antioxidant activities to these compounds are emphasized ${ }^{22,23}$. All these data regarding the antioxidant activity of compounds identified as present in the species in question help to justify their ethnomedicinal use in the treatment of various diseases that have THE as participants of their pathophysiological processes.

\subsection{Antioxidant Activity}

DPPH free radicals are initially purple because they have a free electron. The color change is given when a hydrogen radical is donated by an antioxidant molecule that resonates with the DPPH molecule, having a yellowish color, thus decreasing absorbance. Low absorbance indicates sequestrant activity of free radicals ${ }^{24}$.

The evaluated extract, called EAAc,, proved to be an excellent $\mathrm{H}+$ donor for the DPPH radical. The extract was compared with gallic acid pattern, at a concentration of $1000 \mu \mathrm{g} / \mathrm{mL}$. The EAAc performed $93.2 \%$ while gallic acid $90 \%$. However, the persistence of the antioxidant capacity of gallic acid is superior to that of EAAc. Thus, with the decrease in the concentration of the extract the sequestering activity also decreases. In the phosphomolybdenum assay, the EAAC had a percentage of $46.3 \%$ equivalence to the ascorbic acid pattern, both at a concentration of $1 \mu \mathrm{g} / \mathrm{ML}$ (Table 1). 
Table 1 - Antioxidant activity of aqueous extract of $A$. cearensis.

\begin{tabular}{lll}
\hline Antioxidant Assay & Extract & Default \\
\hline DPPH & $93,3 \pm 0,01$ & $90,0 \pm 0,03$ \\
TAC & $46,3 \pm 0,05$ & $100,0 \pm 0,02$
\end{tabular}

Standards: DPPH - Gallic acid; TAC - ascorbic acid

Corroborating the present study, extracts of $A$. cearensis obtained in the region of Bahia also demonstrated a considerable antioxidant activity in vitro against DPPH radicals, which was correlated with the high concentration of total phenols. Emphasis on ethanol extract with total phenol concentration of $131.14 \mathrm{mg} \mathrm{EAG} / \mathrm{g}$ and $93.13 \%$ antioxidant activity 25 .

The extract of $A$. cearensis seeds obtained in Feira de Santana, Bahia, also showed considerable antioxidant activity, protecting mitochondria from oxidative stress ${ }^{26}$. Moreover, afrormosin, isoflavonoid isolated from the barks of $A$. cearensis collected in the municipality of Quixeramobim, Ceará, has been shown to be a promising inhibitor of neutrophil-mediated inflammatory response; and an antioxidant activity not linked to free radical sequestration, suggesting that other methodologies can be applied to unravel how these molecules act in the face of oxidation ${ }^{27}$.

The values obtained for the sequestration of free radicals in the present study indicate that the extract is a source of antioxidant compounds, since its reducing capacity is indicative of antioxidant activity ${ }^{17}$.

\subsection{Hemotoxic activity}

Plants contain active ingredients responsible for the therapeutic properties attributed to them, however, these can also trigger adverse reactions, which appear due to misuse or direct contact with the specimen ${ }^{28}$. In this sense, in order to ensure the safety of cellular systems, it is interesting to evaluate the toxicity of extracts and natural products, since it is aimed at developing new drugs and therapeutic strategies in the face of diseases associated with oxidative stress $^{29}$.

Hemotoxic or hemolytic activity was used to evaluate the potential of the extract to cause lesions in the plasma membrane of erythrocytes, by pore formation or by total rupture, through optical reading of the consequent release of hemoglobin. In this trial, the EAAc did not promote such activity, unlike the positive control (Triton X- 100 to $1 \%$ ). In the test with the suspension of blood cells, no red staining, characteristic of hemolysis, was verified in the supernatant, and precipitate formation was observed in all tubes, demonstrating that the concentrations tested did not promote hemolysis.

The literature on the investigation of hemolytic activity in natural products obtained from $A$. cearensis is scarce. A single study identified evaluated the in vitro toxicity of molecules isolated from the stem bark of $A$. cearensis campferol, isocampferide, protocatechuic acid and amburosideside $A$. Of these, only protocatecuic acid was able to induce erythrocyte hemolysis ${ }^{30}$. However, this activity was attributed to a single substance in isolation, and this interpretation cannot be extrapolated when considering the synergism of several compounds of an extract.

Hemolysis refers to the process of rupture of the erythrocyte membrane with hemoglobin release. When the body is unable to perform the reuptake of this protein, its plasma levels increase and may pose a health risk, compromising the function of vital organs such as kidneys, liver and heart ${ }^{31}$. Hemolysis can be triggered by the interaction of exogenous substances, such as drugs or compounds present in plants, and the Https://escipub.com/international-journal-of-bioscience-and-medicine/ 5 
various biological systems ${ }^{29}$. Thus, the negative results obtained with the EAAc point to the absence of toxicity to the erythrocyte membrane in the tested model.

\section{CONCLUSION}

In conclusion, the study reveals that the EAAc presented promising results regarding antioxidant activity, as well as did not demonstrate toxicity to human erythrocytes in the evaluated model. These results may be related to the phytochemical content of the extract, in which the presence of flavonoids, coumarins and tannins was seen, compounds with antioxidant capacity already described in the scientific literature. Thus, the extract demonstrates potential for the development of cosmetics and herbal medicines.

\section{REFERENCES}

1. MONTENEGRO, Camila de Albuquerque et al. Bioprospecção dos efeitos tóxicos, antibacterianos e antioxidantes da flavona e de seus derivados hidroxilados. 2015.

2. VASCONCELOS, Inácio Ricardo Alves et al. Investigação dos efeitos antibacteriano, antioxidante, citotóxico e genotóxico do óleo essencial do caule de Croton tricolor Klotzsch ex Baill. 2015.

3. ANDRADE-LIMA, D. Plantas da caatinga. Rio de Janeiro: Academia Brasileira de Ciências, 1989.

4. HILTON-TAYLOR, C. 2000 IUCN red list of threatened species. Cambridge: IUCN, 2000.

5. Ferraz, Elba Maria Nogueira, Rodal, Maria Jesus Nogueira, Sampaio, Everardo V. S. B., \& Pereira, Rita de Cássia Araújo. (1998). Composição florística em trechos de vegetação de caatinga e brejo de altitude na região do Vale do Pajeú, Pernambuco. Brazilian Journal of Botany, 21(1), 7-15

6. BEZERRA, A. M. E.; CANUTO, K. M.; SILVEIRA, E. R. Estudo fitoquímico de espécimens jovens de Amburana cearensis A.C. Smith. In: REUNIÃO ANUAL DA SOCIEDADE BRASILEIRA DE QUÍMICA, 29, 2005, Águas de Lindóia. Anais... Águas de Lindóia: 2005. 2p.

7. VALKO, Marian et al. Radicais livres e antioxidantes em funções fisiológicas normais e doenças humanas. $O$ jornal internacional de bioquímica e biologia celular, v. 39, n. 1, p. 44-84, 2007.

8. DUDONNE, Stephanie et al. Comparative study of antioxidant properties and total phenolic content of 30 plant extracts of industrial interest using DPPH, ABTS, FRAP, SOD, and ORAC assays. Journal of agricultural and food chemistry, v. 57 , n. 5 , p. 1768-1774, 2009.

9. Brand-WIliams, W., Cuvelier, M.E. and Berset, C. (1995) Use of a Free Radical Method to Evaluate Antioxidant Activity. Brazilian Apples. Food and Nutrition Sciences, 6, 727-735.

10. AGUILAR URBANO, Miguel; PINEDA PRIEGO, Manuel; PRIETO, Pilar. Spectrophotometric quantitation of antioxidant capacity through the formation of a phosphomolybdenum complex: specific application to the determination of vitamin E1. 2013.

11. MISHRA, K.; OJHA, H.; CHAUDHURY, N. K. Estimation of antiradical properties of antioxidants using DPPH assay: a critical review and results. Food Chemistry, v.130, p. 1036-1043, 2012.

12. COOPER, K. H. Revolução Antioxidante. $3^{\mathrm{a}}$ ed. Editora Record: Rio de Janeiro, 2005; 249p. ISBN: 9788501042675.

13. JIMOH, F. O.; ADEDAPO, A. A.; AFOLAYAN, A. J. Comparison of the nutritive value, antioxidant and antibacterial activities of Sonchus asper and Sonchus oleraceus. Records of Natural Products, v. 5, p. 29-42, 2011.

14. SOARES, S. E. Ácidos fenólicos como antioxidantes. Revista de nutrição, v. 15, n. 1, p. 71-81, 2002.

15. CANUTO, K. M.; SILVEIRA, E. R. Constituintes químicos da casca do caule de Amburana cearensis AC Smith. Química Nova, v. 29, n. 6, p. 1241, 2006.

16. CANUTO, K. M.; SILVEIRA, E. R; BEZERRA, A. M. E. Estudo fitoquímico de espécimens cultivados de cumaru (Amburana cearensis AC Smith). Química Nova, v. 33, n. 3, p. 662-666, 2010.

17. ABIFARIN, T. O.; AFOLAYAN, A. J.; OTUNOLA, G. A. Phytochemical and antioxidant activities of Cucumis africanus L.f.: a wild vegetable of South Africa. Journal of Evidence-Based Integrative Medicine, v. 24, p. 1-8, 2019.

18. LIM, H.; HEO, M. Y.; KIM, H. P. Flavonoids: broad spectrum agents on chronic inflammation. Biomolecules \& Therapeutics, v. 27, n. 3, p. 241-253, 2019.

19. RUSSO, B. et al. Flavonoids and insulinresistance: from molecular evidences to clinical trials. International Journal of Molecular Sciences, v. 20, n. 9, p. 2061-2078, 2019.

20. SUDHAKARAN, M.; SARDESAI, S.; DOSEFF, A. I. Flavonoids: new frontier for immuno-regulation and breast cancer control. Antioxidants, v. 8, n. 4, p. 103-129, 2019. 
21. KARAKAYA, $S$. et al. The $\alpha$-amylase and $\alpha$ glucosidase inhibitory activities of the dichloromethane extracts and constituents of Ferulago bracteata roots. Pharmaceutical Biology, v. 56, n. 1, p. 18-24, 2018.

22. PEREIRA, A. V. et al. Análise da atividade antimicrobiana de taninos totais de plantas aromáticas do Nordeste brasileiro. Agropecuária Técnica, v. 36, n. 1, p. 109-114, 2015.

23. MELLO, J. C. P.; SANTOS, S. C. Taninos. In: SIMÕES, C. M. O; SCHENKEL, E. P.; MELLO, J. C. P.; MENTZ, L. A.; PETROVICK, P. R. (org.). Farmacognosia: do produto natural ao medicamento. 3. ed. Porto Alegre: Artmed, 2017. p. 441-464.

24. SANTOS, Marcelo Henrique dos et al. Influência do processamento e da torrefação sobre a atividade antioxidante do café (Coffea arabica). Química Nova, v. 30, n. 3, p. 604-610, 2007.

25. SANTOS et al. Avaliação da Atividade Antioxidante dos Compostos Fenólicos Presentes na Amburana cearensis. Orbital: The Electronic Journal of Chemistry, v. 1, n. 1, p. 44-49, 2016.

26. PEREIRA et al. Amburana cearensis seed extract protects brain mitochondria from oxidative stress and cerebellar cells from excitotoxicity induced by glutamate. Journal of Ethnopharmacology, v. 209, p. 157-166, 2017.

27. LOPES, Danielle Branta et al. Comparação do perfil das lactonas produzidas por biotransformação microbiana e biocatálise enzimática a partir dos óleos de mamona e linhaça. 2013.

28. ABIFARIN, Taiwo Oluwafunmilola; AFOLAYAN, Anthony Jide; OTUNOLA, Gloria Aderonke. Phytochemical and Antioxidant Activities of Cucumis africanus Lf: A Wild Vegetable of South Africa. Journal of evidence-based integrative medicine, v. 24, p. 2515690X19836391, 2019.

29. DEWICK, P.M. Medicinal Natural Products: A biosynthetic aproroach. John Wiley \& Sons LTD, $2^{\circ}$ ed., p.291-300. 2002.

30. GHRAMH, H. A.; KHAN, K. A.; IBRAHIM, E. H. Biological Activities of Euphorbia peplus Leaves Ethanolic Extract and the Extract Fabricated Gold Nanoparticles (AuNPs). Molecules, v. 24, n. 7, p. 1431, 2019.

31. COSTA-LOTUFO, Letícia V. et al. Antiproliferative effects of several compounds isolated from Amburana cearensis AC Smith. Zeitschrift für Naturforschung C, v. 58, n. 9-10, p. 675-680, 2003.

32. CARVALHO, E.B. et al. Efeito da bomba de infusão de soluções sobre o grau de hemólise em concentrados de hemácias. Revista Brasileira de
Hematologia e Hemoterapia, v.29, n.2, p. 149-152, 2007.

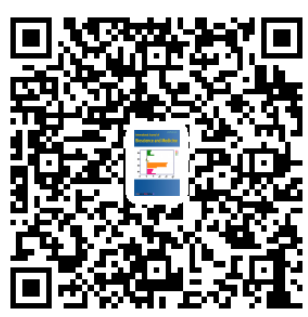

Https://escipub.com/international-journal-of-bioscience-and-medicine/ 